\title{
A new species of Grillotia Guiart, 1927 (Cestoda: Trypanorhyncha) with redescriptions of congeners and new synonyms
}

\section{Ian Beveridge • Ronald A. Campbell}

Received 11 December 2012 / Accepted: 18 March 2013

\author{
I. Beveridge $(\bowtie)$ \\ Department of Veterinary Science, University of Melbourne, Veterinary Clinical Centre, 250 \\ Princes Highway, Werribee, Victoria 3030, Australia \\ e-mail: ibeve@unimelb.edu.au
}

\author{
R. A. Campbell \\ 7473 North Valley Pike, Harrisonburg, VA 22802, USA
}

\begin{abstract}
A new species of Grillotia, G. gastrica n. sp., is described from the stomach musculature of the teleosts Upeneichthys lineatus (Bloch \& Schneider) and Sillaginodes punctatus (Cuvier) from off Perth, Western Australia. The new species most closely resembles G. pristiophori Beveridge \& Campbell, 2001 in having six hooks in each principal row of the metabasal tentacular armature but differs in having a smooth scolex tegument and in having a band of hooklets running the entire length of the external surface of the tentacle rather than diminishing in width to a single hooklet as occurs in G. pristiophori. Grillotia heptanchi (Vaullegeard, 1899) is redescribed and the details of the mature segment are described for the first time. Grillotia adenoplusius (Pintner, 1903) is redescribed from the type-specimens and is considered to be the larval stage of G. acanthoscolex Rees, 1944 (syns G. spinosissima Dollfus, 1969 and G. microthrix Dollfus, 1969). The adult of $G$. adenoplusius is also redescribed based on the types of $G$. spinosissima. The type-specimens of $G$. dolichocephala Guiart, 1935 and G. minor Guiart, 1935 were re-examined and G. minor is considered to be a synonym of G. dolichocephala as is G. meteori Palm \& Schröder, 2001. Based on
\end{abstract}


an examination of the type-specimens, G. scolecina (Rudolphi, 1819) is treated as a species inquirenda. A list is provided of the species currently placed in Grillotia.

\section{Introduction}

During a preliminary phylogenetic study of the Trypanorhyncha, Beveridge et al. (1999) concluded that the genus Grillotia Guiart, 1927 appeared to be a highly heterogeneous assemblage of species. Subsequently, a series of attempts has been made to better define and describe its members (Palm, 2004; Beveridge \& Campbell, 2007, 2010, 2012). Palm (2004) removed a number of species to more appropriate genera such as Pseudogrillotia Dollfus, 1969 [G. epinepheli Scholz, Garippa \& Scala, 1993; G. perelica (Shuler, 1938)] and Pseudolacistorhynchus Palm, 1995 [G. heroniensis Sakanari, 1989, G. matheri (Southwell, 1929) and G. shipleyi (Southwell, 1929)], while erecting a new genus, Grillotiella Palm, 2004, for Rhynchobothrium exile Linton, 1909 (and its synonym $G$. branchi Shaharom \& Lester, 1982) and adding G. yuniariae Palm, 2004 and G. (Progrillotia) dollfusi Carvajal \& Rego, 1983 to the genus. Palm (2004) retained the latter combination because of homonymy with G. dollfusi Carvajal, 1971, a morphologically different species.

Subsequently, Beveridge \& Campbell (2007) redescribed the type-species G. erinaceus van Beneden, 1858 and closely related species, tentatively referred to by them as members of the erinaceus complex [G. borealis Keeney \& Campbell, 2001, G. brayi Beveridge \& Campbell, 2007, G. erinaceus, G. dollfusi, G. musculara (Hart, 1936)]. Recently, an additionl species, G. patagonica Menoret \& Ivanov, 2012, has been added to this group by Menoret \& Ivanov (2012). Beveridge \& Campbell (2010) reviewed the "Christianella" group of species within the genus [G. (C.) australis Beveridge \& Campbell, 2011, G. (C.) carvajalregorum Menoret \& Ivanov, 2009 (syn. Progrillotia dollfusi Carvajal \& Rego, 1983), G. (C.) longispinis (Linton, 1890), G. (C.) minuta van Beneden, 1849 (syns $G$. (C.) angeli Dollfus, 1969, G. (C.) bothridiopunctata Dollfus, 1969, G. (C.) smarisgora (Wagener, 1854), and G. (C.) yuniariae] establishing this group on a provisional basis as a sub-genus.

Beveridge \& Campbell (1912) removed G. rowei Campbell, 1977 and G. kovalevae Palm, 1995 to a new genus Bathygrillotia Beveridge \& Campbell, 1977 based on the observation of Palm (2004) that the armature of the external surface of the tentacle was unique within the genus.

Here, we describe a new species of Grillotia from Australia as well as redescribe G. heptanchi (Vaullegeard, 1899) and G. adenoplusius Pintner, 1903 and provide a number of new synonymies 
based on the re-examination of type-specimens in European museums. The current status of species within the genus is discussed.

\section{Materials and methods}

Specimens were examined from all museums known to hold collections of Grillotia. These included the British Museum (Natural History), London (BMNH), sometimes referred to as The Natural History Museum, the Institut Océanographique de Monaco (IOM), the Muséum d'Histoire naturelle, Geneva (MHNG), the Muséum national d'Histoire naturelle, Paris (MNHN) and the Naturhistorisches Museum, Vienna (NMV). New specimens have been deposited in the South Australian Museum, Adelaide (SAM).

Newly collected specimens were fixed in $70 \%$ ethanol, stained in Celestine Blue, dehydrated in ethanol, cleared in methyl salicylate and mounted in Canada balsam. Drawings were made using a drawing tube attached to an Olympus BH microscope. Measurements are given in micrometres unless otherwise stated as the mean followed by the range and the number of measurements made. Vitelline follicles are shown only at the lateral margins of segments.

Terminology for morphological features peculiar to trypanorhynch cestodes follows Dollfus (1942), Campbell \& Beveridge (1994) and Jones et al. (2004). Host nomenclature follows

Eschmeyer (1998). For known species, only principal synonyms are provided. Additional details are available in Dollfus (1942) and Palm (2004).

\section{Grillotia gastrica n. sp.}

Type-host: Upeneichthys lineatus (Bloch \& Schneider).

Site in host: Musculature of the stomach wall.

Type-specimens: SAM, holotype 35621, 4 paratypes 35622-3 (whole mounts).

Type-locality: Off Perth, Western Australia (31 ${ }^{\circ} 57^{\prime} \mathrm{S}$; 11552’E). Collected 22.xi.2011 by A. Jabbar \& I. Beveridge.

Other material examined: Three plerocerci from stomach wall of Sillaginodes punctatus (Cuvier), off Perth, Western Australia (SAM 35624).

Etymology: The name is based on the location of the plerocerci in the stomach wall. 


\section{Description (Figs. 1-8)}

[Based on types; means of 5 measurements]. Small cestodes, scolex 1,236-1,743 $(1,308)$ long, 175-216 (200) wide in pars vaginalis, 247-288 (270) wide in pars bulbosa; two patelliform bothria, with slight indentation at posterior margin; bothrial groove prominent; pars bothrialis 340-577 (412), bothrial width 443-453 (448); pars vaginalis without prominent microtriches on tegument, 783-1,050 (917) long; tentacle sheaths highly sinuous except at anterior extremity; bulbs short, 350-422 (385) long, 82-93 (84) wide; bulb ratio (bulb length to width) 1: 3.8-5.5 (1: 4.6); prebulbar organ and gland cells within bulb absent; retractor muscle originates in anterior half of bulb. Scolex ratio (pars bothrialis : pars vaginalis : pars bulbosa) $1: 1.8-2.7: 0.8-1.0$ ( $1: 2.2: 0.9$ ).

Tentacles elongate, longest everted tentacle 1,490; tentacle diameter 21-31 (24) in metabasal region, with distinct basal swelling, 31-41 (36) in diameter. Armature heteroacanthous, atypical, heteromorphous; hooks hollow; hook rows commence on internal surface of tentacle, terminate on external surface, with space between hook files 1 and 1' on internal surface; distinct basal armature present. Initial 2 hook rows with uncinate hooks 10-21 (15) long, base 7-12 (10) long; next 3 rows consist of 2-3 hooks only; hooks 1(1') falcate 21-31 (25) long, base 9-12 (11) long; hooks 2(2') and 3(3') smaller, 13-21 (17) long, base 4-10 (7) long. Hooks 1(1') of rows 6 and 7 greatly enlarged, uncinate with elongate base, 20-24 (22) long, base 12-23 (16) long; hooks 1(1') of rows 8 and 9 small uncinate; rows 6-9 contain 3-4 hooks on each side of tentacle; metabasal armature commences at row 10; on external surface of tentacle, area distal to 2 initial hook rows free of hooks; area opposite hook rows 5-7 with small, well-spaced spiniform hooks with prominent bases, 2-7 (6) long, base 1-3 (2) long, extending to mid-region of basal swelling; distal region of external surface of swelling with closely packed array of small uncinate hooks c.2 long, base c. 1 long; array composed of about 12 rows of hooks; metabasal armature commences immediately distal to array. Principal rows with 6 hooks; hooks 1(1') uncinate with elongate base, 12-16 (14) long, base 8-13 (11) long; hooks 2(2') longer, erect-uncinate with elongate base, 16-23 (20) long, base 6-13 (11) long; hooks 3(3') falcate with short base, 18-26 (21) long, base 6-10 (8) long; hooks 4(4') falcate, slightly shorter, 12-26 (19) long, base 5-6 (6) long; hooks 5(5') falcate, 14-23 (19) long, base 4-6 (5) long; hooks 6(6') falcate, 14-22 (18) long, base 4-6 (5) long; 1-3 rows of spiniform intercalary hooks present with 2-5 hooks per row, c.3 long, base $c .1$ long; intercalary hooks merge with band of 
hooklets on external surface of tentacle; band of hooklets 8-10 wide extends along entire length of metabasal region; hooklets tiny, spiniform, c. 2 long, base 0.5 long. Strobila not known.

\section{Remarks}

As this species possesses two bothria and an atypical heteroacanthous armature with a continuous band of hooks on the external surface of the tentacle, it belongs within the genus Grillotia. As G. gastrica $\mathrm{n}$. sp. possesses six hooks in each principal row, it is readily distinguished from all members of the Grillotia erinaceus complex and members of the sub-genus Christianella, all of which have only four hooks in each principal row. Likewise, it differs from G. adenoplusius (syn. G. acanthoscolex; see below) and G. heptanchi which have five hooks in each principal row and from G. amblyrhynchos and G. dolichocephala (syn. G. meteori; see below) which have seven hooks in each principal row. Grillotia heptanchi has been described as having six hooks in each principal row (Dollfus, 1942; Palm, 2004) but hooks 6(6’) are in fact enlarged terminal hooks in an intercalary row (see below). The only other species of this genus which possesses six hooks in each principal row is G. pristiophori Beveridge \& Campbell, 2001. The armature on the external surface of the basal swelling of G. gastrica resembles that of G. pristiophori in that distal to the initial two rows of hooks, there is an area free of hooks, followed by an area of elongate, well-spaced hooks and then by a compact array of hooklets. The two species differ in that the band of hooklets present distal to the compact array in G. pristiophori, rapidly diminishes in width and becomes a simple chainette with one hooklet per principal row. In addition, the specimens of G. gastrica n. sp. have a smooth scolex tegument lacking prominent microtriches, while that of G. pristiophori is covered with enlarged microtriches. As a consequence, specimens of G. gastrica n. sp. described here clearly differ from all known congeners and are considered to be new.

\section{Grillotia heptanchi (Vaullegeard, 1899) Dollfus, 1942}

Syns Rhynchobothrium erinaceus van Beneden, 1858 sensu Zschokke (1887); Tetrarhynchus heptanchi of Pintner, 1896: Vaullegeard, 1899; Heterotetrarhynchus institatum Pintner, 1931; Tentacularia megabothridia Hart, 1936 
Material examined:

Adults: from Hexanchus griseus (Bonnaterre), 8 specimens (identified as Grillotia institata), Naples, Italy, coll. F. Zschokke, 17.i.1886 (MHNG 37258, 37263, 40835); 2 specimens (identified as Tentacularia megabothridia), Puget Sound, USA, coll. J. E. Lynch, 1937 (MHNG 3573.2); 2 slides of gravid segments, Trieste, Italy, coll. T. Pintner (NMV 3530-1).

Plerocerci: 5 specimens, from body muscles, Lepidorhombus whiffiagonis (Walbaum)

(=Zeugopterus megastoma), Marché de Paris (MNHN Bd 19-79); 2 specimens, from muscle, Molva dypterygia (Pennant), “S.S.Thalassa” stn B248 (MNHN Bd 19:77-79).

Redescription (Figs. 9-18)

[Measurements of 5 gravid and mature specimens unless otherwise indicated, from Hexanchus griseus in MHNG]. Gravid specimen 33 mm long with 70 segments; scolex acraspedote, 4.1-5.8 (5.2) $\mathrm{mm}$ long, maximum width in region of pars bulbosa 810-990 (920); 2 bothria, patelliform in shape; pars bothrialis 1,050-1,340 (1,210) long; width of bothria 700, $870(n=2)$; pars vaginalis 2,350-3,650 (3,090) long; sheaths sinuous; bulbs 1,600-2,300 (2,000) long, 350-420 (390) wide, bulb ratio 1: 4.57-5.61 (1: 5.15); retractor muscle originates in anterior quarter of bulb; pars postbulbosa short $(0.05)$ or absent; scolex ratio $1: 2.20-2.86: 1.550-1.86$ (1:2.57: 1.67).

Tentacular armature heteroacanthous, atypical, heteromorphous; hooks hollow; basal swelling and distinctive basal armature absent. Principal rows of hooks begin on internal surface of tentacle, terminate on external surface; prominent space between hooks 1 and 1'; 5 hooks per principal row; hooks 1(1') large uncinate, 79-98 (89) long, base 71-79 (76) long; hooks 2(2') erect falcate, 72-82 (77) long, base 37-43 (39) long; hooks 3(3') falcate, 63-71 (68), base 21-31 (28) long; hooks 4(4') falcate, 53-62 (58) long, base 12-19 (15) long; hooks 5(5') falcate, 46-54 (50) long, base 13-16 (15) long. Intercalary hooks spiniform, arranged in 4 rows; anterior row with about 8 hooks, 15-30 (24) long, base 3-6 (4); terminal hook (Fig. 13 A) greatly enlarged, 59-71 (66) long, base 12-18 (14); second and third rows with 5 to 6 hooks, fourth row with 2-3 hooks, almost aligned with principal row; external surface with narrow longitudinal band of hooklets, merging with intercalary rows, 24-32 (26) long, base 4-7 (5).

Segments prominently craspedote; mature segments much longer than wide, $2.41-4.32$ (3.31) $\mathrm{mm}$ long, 0.93-1.12 (1.01) $\mathrm{mm}$ wide; genital pore in posterior half of segment, 0.79-1.69 (1.25) $\mathrm{mm}$ from posterior end; genital pores alternate irregularly with parenchymal thickenings 
anterior and posterior to opening; hermaphroditic duct cavity voluminous, 107-110 (n=2) deep, 57$75(\mathrm{n}=2)$ wide with thick walls, surrounded by cirrus-sac; cirrus-sac elongate with proximal pole directed antero-medially, 230-310 (270, n=3) long; inverted cirrus terminates proximally within elongate internal seminal vesicle; when everted, genital atrium forms large basal peduncle; cirrus unarmed; external seminal vesicle present, 99-107 ( $\mathrm{n}=2)$ long, 32-64 (n=2) wide, emptying into internal seminal vesicle; vas deferens greatly coiled, proximal coils with prominent glandular cells; testes scattered in several layers throughout medulla, pre- and post-ovarian, approx. 520 in number, 62-89 (73, n=10) long, 46-62 (54, n=10) wide.

Vagina ventral to cirrus-sac; opening to hermaphroditic duct; vaginal wall surrounded by layers of gland cells; vagina runs medially and posteriorly towards ovarian isthmus; ovary bilobed in dorso-ventral view, lobes 128-305 (206) long, 107-192 (163) wide; Mehlis' gland 114-192 (149) in diameter. Vitelline follicles circummedullary, interrupted only at level of genital atrium; uterus median, tubular, with uterine pore, extending anterior to genital atrium; ventral osmoregulatory canal broad, c.39 in diameter; dorsal canal narrower, $c .12$ in diameter.

Gravid segments 3.31-5.73 (4.59) $\mathrm{mm}$ long, 1.32-1.74 (1.51) $\mathrm{mm}$ wide; genital pore in posterior half of segment, 1.62-1.94 (1.76) mm from posterior end; uterus saccate, extending anteriorly beyond uterine pore.

\section{Remarks}

This species was first reported under the name "Tetrarhynchus aus Heptanchus" by Pintner (1896) and was subsequently designated by the binomial Tetrarhynchus heptanchi by Vaullegeard (1899). Although Pintner (1931) eventually named the same species Heterotetrarhynchus institatum, Vaullegeard's binomial has priority. The species was transferred to Grillotia by Dollfus (1942).

The tentacular armature of $G$. heptanchi was described and illustrated in great detail by Dollfus (1942) based on plerocerci, and excellent SEMs of it were provided by Palm (1995), all from fish collected in the Atlantic Ocean. Rees (1950) provided a detailed description of the plerocercus, also based on specimens probably collected in the Atlantic Ocean, while aspects of the histology of the adult have been described by Pintner (1931) (as Heterotetrarhynchus institatum) from specimens collected from $\mathrm{H}$. griseus in the Mediterranaean Sea although he only provided schematic illustrations of the mature and gravid segments. Hart (1936) described the species from the eastern coast of the USA but provided only a schematic illustration of the mature segment (as 
Tentacularia megabothridia). Wardle (1933) also reported the species [as Grillotia erinacea (sic)] from the Straits of Georgia in western Canada but provided only a very brief description. In discussing the identification of his specimens, Wardle (1933) considered only three species, $G$. erinaceus, G. institatum (the former name of G. heptanchi) and G. scolecinus, but did not explain why he considered them to be conspecific with G. erinaceus. Dollfus (1942) attributed the specimens to G. heptanchi presumably on the basis of the host Hexanchus griseus (syn. H. caurinus) and based on the statement by Wardle (1933) that there were "numerous hooks of 5 types arranged in circum-proboscideal rows". If this observation is correct and there were five hooks in each principal row, then the specimens belong to $G$. heptanchi. Wardle (1933, figure 2) provided a photograph of a plerocercus of $G$. heptanchi from a species of Theragra sp. but the photograph was taken at a low magnification and does not allow identification of the specimen. However, the specimen was subsequently sent to Dollfus who used it to illustrating the armature of this species (Dollfus, 1942, figures 274-275) and thereby confirming its identity. The species was also summarily described by Tseng (1933) under the name Otobothrium linstowi Southwell, 1912 from a specimen collected from Notorhynchus cepedianus (Péron) (=Notorhynchus platycephalus Tenore) from off Qingdao (Tsingtao in Dollfus, 1942), Shandong Province, China. Dollfus (1942) allocated this record to $G$. heptanchi presumably based on the fact that figure 14 of the scolex by Tseng (1933) shows no bothrial pits and the segment (figure 16 of Tseng, 1933) is characteristically craspedote. Her figure of the armature shows only the internal surface (Tseng, 1933) but it is consistent with that of $G$. heptanchi. However, the details of segment morphology were not described.

As a consequence, although this species is quite well known, there are no detailed descriptions of the morphology of mature segments, in particular the terminal genitalia. Host records have been summarised by Bates (1990) and Palm (2004).

The species has a characteristic tentacular armature with five hooks per principal row and enlargement of the terminal hook of the first intercalary row. Pintner (1931), Rees (1950) and Palm (2004) considered that there were six hooks in each principal row [although they were numbered in the reverse order by Pintner (1931)]. Dollfus (1942) however, observed that the sixth hook did not belong to the principal row but numbered it as such purely for convenience. As it is clearly the terminal hook of the first intercalary row, it has not been designated as a sixth hook in this redescription following Beveridge \& Campbell (2001).

Although this species is apparently well known, there are few specimens of it available in collections and consequently a complete description of the mature segment cannot be given. It was 
however possible to provide more detail that is currently available. The specimens upon which the redescription is based are primarily those collected by Zschokke (1887) under the name Rhynchobothrium erinaceus which he did not describe (Dollfus, 1942) but gave to Pintner who based his description of G. heptanchi upon them. The specimens are now in MHNG labelled "leg. Pintner". Given that Pintner examined the specimens, it is surprising that his description of the terminal genital ducts differs significantly from the present description. The morphology of the terminal genital ducts is highly unusual and the observations made here needs to be confirmed when material becomes available for sections. What at first sight appears as a thick walled genital atrium is in fact within the distal region of the cirrus sac and has therefore been designated an hermaphroditic duct. It resembles in some respects the hermaphroditic vesicle seen in Hornelliella annandalei (Shipley \& Hornell, 1906) as redescribed by Campbell \& Beveridge (1987) although in the latter species both hermaphroditic duct and vesicle are present. The inverted cirrus projects into the internal seminal vesicle, resembling the situation found in the gilquiniid genera Aporhynchus Nybelin, 1918, Deanicola Beveridge, 1990, Gilquinia Guiart, 1927, Plesiorhynchus Beveridge, 1990 and Sagittirhynchus Beveridge \& Justine 2006 (see Beveridge, 1990; Beveridge \& Justine, 2006) as does the presence of an external seminal vesicle opening into the side of the internal seminal vesicle. Pintner (1931) also described an accessory seminal vesicle although this structure was not identifiable in the present material. When everted, the hermaphroditic duct forms a peduncular-like structure from which the cirrus projects with the vagina reaching the atrium. It would appear however that the peduncle also occludes the vaginal opening. A similar peduncular structure is found in H. annandalei.

The accepted definitive host for this cestode species is the widely distributed shark $H$. griseus, with its numerous synonyms. However, a new species described more recently, $H$. nakamurai Teng, may also occur in the Mediterranean and elsewhere (Eschmeyer, 1998) and should be considered as a possible alternative host for this cestode. Early records now require verification by additional collections from carefully identified hosts.

\section{Grillotia adenoplusia (Pintner, 1903) Palm, 2004}

Syns Rhynchobothrius adenoplusius Pintner, 1903; Grillotia acanthoscolex Rees, 1944 (new synonym); Grillotia spinosissima Dollfus, 1969; Grillotia microthrix Dollfus, 1969. 


\section{Material examined:}

From Lophius piscatorius Linnaeus: types of $R$. adenoplusius, plerocerci, Naples, Italy, coll. T. Pintner 21.iii.1899 (NMV 2050-3, 2009).

From Hexanchus griseus: syntypes of G. acanthoscolex, Porcupine Bank, Atlantic Ocean (BMNH 1976.4.13.48-49); syntypes of G. spinosissima (5 specimens, 6 slides), Sète, France, coll. L. Euzet, January 1952 (MNHN Bd 16.36-38); 3 specimens (5 slides), Monterey Bay, California, coll. N.W. Riser, 24.vi.1947 (MNHN Bd 29.7-9).

From Torpedo nobiliana Bonaparte: type of G. microthrix, Sète, France, coll. L. Euzet, 5.v.1954 (MNHN Bd 16.34).

Redescription of plerocerci of G. adenoplusia (Figs. 19-22)

[Measurements from 3 plerocerci]. Scolex length 740-900 (820); 2 bothria without prominent margins, slightly indented posteriorly, pars bothrialis 330-370(350), bothrial width 420-490 (460); pars vaginalis 440-610 (530) long, tegument covered with enlarged microtriches; tentacle sheaths slightly sinuous in pars bothrialis, coiled in pars vaginalis; bulbs short, bulb length 210-240 (220), bulb width 50-80 (70), bulb ratio 1: 3-4.2 (1: 3.4); prebulbar organ and gland cells within bulb absent; retractor muscle originates at base of bulb, nuclei within retractor muscle prominent; pars post-bulbosa present. Tentacles partly everted on single specimen only (Fig. 19); first row of hooks small, uncinate; principal rows begin immediately after initial row; hook 1 (only one side of tentacle visible), slender falcate, 14-23 (18, $n=4)$ long, base 9-13 (11, $n=4)$ long; hooks 2 of second and third rows falcate, greatly enlarged; hook 2 of first row 33 long, base 14 long, second row 53 long, base 20 long, third row 46 long, base 18 long; hooks 3-5 much smaller, falcate, 10-18 (14, n=5) long, base 3-5 (4, n=5); series of elongate falcate hooks present on antibothrial surface, number in hook row impossible to determine, 30-33 (31, n=2) long, base 9=11 (10, n=2) long; cluster of tiny hooklets present on antibothrial surface at termination of hook row 3.

Redescription of adults from H. griseus (Figs. 23-31)

[Based on specimens in MNHN; measurements of scolex based on 3 specimens from California and one type-specimen - the remaining scoleces in the type series are damaged). Scolex length 1,150-1,560 (1,330, n=4); maximum width 350-500 (400, $n=4)$; scolex covered with spines 
(microtriches) extending as far posteriorly as anterior region of pars bulbosa; 2 patelliform bothria without thickened rims; pars bothrialis 400-550 (470, n=4), width of bothria 600; pars vaginalis 710-900 (810, n=4); sheaths sinuous; bulbs 410-470 (440, $\mathrm{n}=4)$ long, width 90-120 (110, $\mathrm{n}=4)$; bulb ratio $1: 3.4-1: 4.6(1: 4.2, \mathrm{n}=4)$; retractor muscle originates near base of bulb; pars postbulbosa absent; scolex ratio $1: 1.6-1.9: 0.8-1.20(1: 1.7: 0.95, \mathrm{n}=4)$.

Tentacular armature heteroacanthous, atypical, hooks heteromorphous; basal swelling and distinctive basal armature present. Principal rows of hooks begin on internal surface of tentacle, terminate on external surface; prominent space between hooks 1 and 1'; hooks hollow; 5 hooks per principal row; hooks 1(1') large uncinate, 23-25 (24, n=5) long, base 15-16 (16, n=5); hooks 2(2') erect falcate, 27-29 (28, n=5) long, base 8-10 (9, n=5); hooks 3(3') falcate, 21-28 (26, n=5), base 5-9 (8, n=5); hooks 4(4') falcate, 15-21 (20, n=5) long, base 5-8 (6, n=5); hooks 5(5') falcate, distant from hooks $4\left(4^{6}\right), 20-24(19, n=5)$ long, base 5-6 (6, n=5). Intercalary hooks usually paired, one anterior to the other, small, spiniform, 6-12 (9, n=5) long, base 2-3 $(3, n=5)$; external surface with broad longitudinal band of hooklets, merging with intercalary hooks, $2-4(3, n=5)$ long; in some regions of the tentacle, three intercalary hooks present. Initial row of hooks of basal armature uncinate, 20-26 (22, n=5) long, base 12-18 (15, n=5); first 4 hooks 1' billhook-shaped with very broad base, 26-33 (31, n=5) long, base 14-23 (18, n=5); hooks 2' extremely long, falcate, 33-55 $(48, n=5)$, base 13-27 (19, n=5); hooks 3' uncinate, 33-51 (40, n=5) long, base 7-27 (14, n=5); first 4 hooks 1 hastate or with sinuous tips (third and fourth hook), 30-38 (33, n=5) long, base 15-23 $(17, n=5)$; hooks 2 slender falcate, 31-51 (37, $n=5)$ long, base 6-12 $(9, n=5)$; transition to metabasal armature occurs $c$. row 5; on external surface, $c .8$ rows of small spiniform hooks 5-20 (11, n=5) long, base 1-3 (2, n=5), leading into compact array of tiny uncinated hooks $c .4$ long, base $c .1$; array with $c .8$ files and 15 rows, leads anteriorly into band of hooks of metabasal region.

Maximum number of segments 16; segments acraspedote; terminal segments immature with testes visible but no obvious female genitalia, 620-1,210 (960, n=5) long, 290-450 (380, n=5) wide. Detached (probably hyperapolytic) segments 3.5-5.6 (4.8, n=5) mm long, 0.73-1.19 (0.87, n=5) $\mathrm{mm}$ wide; genital pore in posterior half of segment, 1.8-2.6 (2.2, $\mathrm{n}=5) \mathrm{mm}$ from posterior end; genital atrium with muscular thickenings anterior and posterior; cirrus sac 195-289 (257, n=5) long, 133-187 (164, n=5) wide with inverted cirrus projecting into internal seminal vesicle; external seminal vesicle empties in to internal seminal vesicle on lateral aspect; vas deferens convoluted; testes scattered through medulla, 23-62 $(40, n=10)$ in diameter; testes number 136-185 $(160, n=2)$, 
with $c .10$ testes posterior to female genitalia. Termination of vagina not seen; vagina runs ventral to cirrus sac, then posteriorly towards ovarian isthmus; ovary bi-lobed in dorso-ventral view, lobes 195-390 (296, n=5) long, 125-172 (156, n=5) wide; Mehlis' gland posterior to ovarian isthmus, c.150 in diameter; vitelline follicles circum-medullary; uterus not clearly visible; eggs tanned, irregularly ellipsoidal, c.90 long, 40 wide (measured in uterus of whole mounts).

\section{Remarks}

Grillotia adenoplusia is represented only by a series of plerocerci from Lophius piscatorius from Naples held in NMV. The tentacles are everted in a single specimen only, but illustrations of this specimen (Fig. 19) indicate that the scolex is covered with visible microtriches and that the armature visible on the partially everted tentacle is virtually identical to that of $G$. spinosissima and $G$. acanthoscolex. The orientation of the armature could not be determined with certainty and appears to be from the bothrial to the antibothrial surfaces. However, this needs to be verified. Pintner (1903, figure 26a) provided an illustration of the same specimen, but failed to illustrate the enlarged microtriches. He also provided an excellent illustration of the armature (1903, figure 26b), almost identical to that (Fig. 22) in the present paper but it appears that subsequent workers have overlooked Pintner's description and illustrations. Grillotia adenoplusia is therefore here treated as synonymous with G. acanthoscolex. However, it should be noted that there are slight differences in the site of attachment of the retractor muscle and overall measurements as well as difficulties in being able to confidently determine the orientation of the armature in the plerocercus. Consequently, the synonym is made with a degree of caution, but the striking identity of the visible armature and the pars vaginalis covered with prominent microtriches suggest that G. adenoplusia is the intermediate stage of $G$. acanthoscolex. The only other species of Grillotia with a spinose tegument is G. pristiophori, but it differs from the present species in having much more elongated bulbs and in having a series of elongate hooks proximal to the compact array of hooks on the external surface of the basal swelling.

G. spinosissima and G. microthrix were synonymised with G. acanthoscolex by Palm (2004) based on the fact that they all have visible microtriches on the scolex and/or have been found in $H$. griseus. The tentacles of the type-specimens of G. acanthoscolex are not fully everted but what can be seen of the basal armature is identical with that of G. spinosissima. Palm (2004) provided a composite description of the species based on data from Rees (1944) and Dollfus (1969). Of the material available, most is clearly identifiable as G. spinosissima and therefore the present 
redescription is based on the type-specimens of G. spinosissima from H. griseus from the Mediterranean as well as additional specimens from the same host species from California. The specimens from California were apparently sent to Dollfus by Nathan Riser and Dollfus considered them to be a new species, to be named $G$. riseri based on indications on the labels. However, as there appear to be no differences in morphology or measurements between the two sets of specimens (from the same host species), data from both have been combined. The types of G. spinosissima are extremely flattened so that only few measurements can be made from these specimens and both sets of specimens consist of fragmented material so it has been necessary to assume that all the identified material (particularly the detached mature and gravid segments) does in fact belong to this species. Additional collections will be needed to confirm the observations made here, but the current redescription of the species is the most detailed to date providing comprehensive measurements and drawings of the armature for the first time.

Key morphological features of this species are the five hooks in the principal rows, a feature shared only with $G$. heptanchi, and two (occasionally three) intercalary hooks, one aligned anterior to the other posterior to each principal row. A comprehensive series of measurements is provided for the first time. The basal armature has large falcate hooks similar to those seen in species of Grillotia (Christianella), but the remaining hooks are distinctive and different to those observed in this subgenus (Beveridge \& Campbell, 2010). The distinctive billhook-shaped hooks 1 on the base are similar to those seen in Pseudolacistorhynchus nanus Beveridge \& Justine, 2007, but have not been reported in any other species (Beveridge \& Justine, 2007).

Not all details of the terminal genital could be observed in the specimens available, but it appears that both internal and external seminal vesicles are present with the external vesicle emptying into the side of the internal vesicle, similar to the arrangement seen in G. heptanchi.

\section{Grillotia dolichocephala Guiart, 1935}

Syns Grillotia minor Guiart, 1935 (new synonym); Grillotia meteori Palm \& Schröder, 2001 (new synonym).

Material examined: 
From Centroscymnus coelolepis Barbosa du Bocage: syntypes of G. dolichocephala, 3 plerocerci (from skin), St George, Azores, 1902 (IOM Inv 19962-4).

From Centrophorus squamosus (Bonnaterre) (= Lepidorhinus squamosus): type of G. minor, plerocercus, Golfe de Gascogne (IOM Inv 19965).

From Deania profundorum (Smith \& Radcliffe): types of G. meteori, plerocerci, Great Meteor Bank, Atlantic Ocean (BMNH 2000.8.31-5-6).

Redescription (Figs. 32-34)

[Based on lectotype as designated here from Centroscymnus coelolepis, IOM Inv 19963-4]. Scolex length $4.2 \mathrm{~mm}$, width in pars vaginalis 620; attached bladder $4.7 \mathrm{~mm}$ long, $2.6 \mathrm{~mm}$ wide; pars bothrialis 900 long, bothrial width 1,040; pars vaginalis $3.35 \mathrm{~mm}$ long; bulbs 1.02-1.21 (1.09, $\mathrm{n}=4)$ mm long, 260-280 (270, $\mathrm{n}=4)$ wide, bulb ratio $1: 3.71-4.65(1: 4.09, \mathrm{n}=4)$; scolex ratio $1: 3.72$ : 1.21 .

Tentacular armature heteroacanthous, atypical; hooks heteromorphous, hollow; hook rows begin on internal surface of tentacle, terminate on external surface; space between hooks 1 and 1' on internal surface; principal rows consist of 7 hooks; basal swelling absent; distinctive basal armature present. Metabasal armature: hooks 1(1') uncinate with broad base, 60-65 (63, n=5) long, base 35-40 (38, n=5) long; hooks 2(2') falcate, 48-58 (54, n=5) long, base 25-30 (28, n=5) long; hooks 3(3') falcate, smaller, 38-60 (50, n=5) long, base 20-28 (24, n=5) long; hooks 4(4') falcate, slightly smaller, 33-63 (53, $n=5)$, base 18-23 (21, n=5) long; hooks 5(5') falcate 40-50 (45) long, base 15 (15) long; hooks 6(6') falcate. 18-28 (23, n=23) long, base 5-8 (6, n=5) long; hooks 7(7') falcate, 35-53 (46, n=5) long, base 10-20 (14, n=5) long. Two intercalary rows of hooks, first row commencing posterior to hooks 4(4'), second row shorter commencing posterior to hooks 6(6'); 2 rows of 3-5 intercalary hooks spiniform, 18-25 (23, n=5) long, base 3-5 (4, n=5) long; band of spiniform hooklets present on external surface, hooklets $13-18(15, \mathrm{n}=5)$ long, base 5-8 $(6, \mathrm{n}=5)$ long. Basal armature, first 2 principal rows, hooks uncinate, 20-35 (29, n=5) long, base 5-12 (9, $\mathrm{n}=5)$ long; third row with enlarged falcate hooks, hooks 1(1') of third row 65-75 (69, n=3) long, base 65-68 (66, n=3) long; remainder of hooks of row larger, 25-63(44, n=5) long, base 15-33 (24, $\mathrm{n}=5$ ) long. External surface of base of tentacle with compact array of hooklets $c .13$ long, base 8 long. 
Remarks

No types were specifically designated for this species by Guiart (1935). However, slide IOM Inv 19963-4 contains two specimens, one with no tentacles everted and labelled as G. scolecina (Rudolphi, 1819) and the other labelled as G. dolichocephala. The second specimen is identical with that illustrated by Guiart (1935, figure 56) and is here nominated as the lectotype as it is the only specimen attributed to the species with everted tentacles as well as having been illustrated by Guiart (1935). The redescription presented above is based on the lectotype. An additional specimen (IOM Inv 19962) from the same host has no evaginated tentacles but the hook pattern observable is indistinguishable from that of $G$. dolichocephala and a spirit specimen (IOM Inv 10064) labelled as G. scolecina is also indistinguishable from G. dolichocephala and is therefore considered to belong to this species. An additional specimen from the muscles of Pseudotriakis microdon Capello, also identified as $G$. dolichocephala (IOM Inv 19961) has no everted tentacles, but examination of the inverted tentacle armature indicates that it does not belong to this species. The specimen cannot be identified further and has not been included among the known hosts of G. dolichocephala.

Grillotia minor is represented by a single specimen (IOM Inv 19965) and was illustrated by Guiart (1935, figure 57). The tentacles of this specimen are not everted and examination of the hook pattern in the inverted tentacles reveals no obvious differences from G. dolichocephala. As a consequence, G. minor is considered to be a junior synonym of G. dolichocephala.

Features of the redescription of $G$. dolichocephala suggested a close relationship with the description of G. meteori given by Palm \& Schröder (2001). A close comparison of measurements and morphological characteristics of the two species revealed no significant differences and as a consequence, G. meteori is treated here as a synonym of G. dolichocephala.

\section{Species inquirendae}

\section{Grillotia hippoglossi (Olsson, 1869) Dollfus, 1942}

Syn. Tetrarhynchus hippoglossi Olsson, 1869

\section{Remarks}


This species was named by Olsson (1869) based on plerocerci found in Hippoglossus hippoglossus (Linnaeus) (= H. vulgaris Fleming) at Storeggen, Norway. The species was redescribed by Bergman (1903) based on plerocerci from the muscles of the same host species collected in Norway. Dollfus (1942) considered the species to be inquirenda. Apparently there are no type-specimens.

\section{Grillotia scolecina (Rudolphi, 1819) Guiart, 1927}

Syn. Tetrarhynchus scolecinus Rudolphi, 1819.

Material examined: 5 slides of plerocerci from Scyliorhinus stellaris (Linnaeus) (= Squalus stellaris) (MNV 2061), Naples; labels read “det Rudolphi, original, don. Pintner”.

\section{Remarks}

The slides contain 16 metacestodes of which only a single tentacle is everted and on that tentacle, most of the hooks have been lost. Consequently, the species is unidentifiable from its type specimens and remains a species inquirenda.

\section{Discussion}

Revisions and redescriptions of species of Grillotia in recent years have resulted in the recognition of two clearly defined species groups. The so-called erinaceus group (G. borealis, G. brayi, G. dollfusi, G. erinaceus, G. musculara, G. patagonica), which we hereby recognise as the subgenus Grillotia, is characterised by four hooks per principal row with hook 4 always distinctly separated from hook 3 and by several rows of intercalary hooks (Beveridge \& Campbell, 2007). The Christianella group, currently defined as a subgenus (Beveridge \& Campbell, 2010) [G. (C). australis, $G$. (C). carvajalregorum, $G$. $(C)$. longispinis, $G .(C)$. minuta, and $G$. $(C)$. yuniariae) again as having 4 hooks in each principal row with hook 4 always distinctly separated from hook 3 but with only a single row of intercalary hooks (Beveridge \& Campbell, 2010) (Table 1). This leaves a heterogeneous collection of apparently valid species (G. adenoplusia, G. amblyrhynchos, G. dolichocephala, G. gastrica, G. heptanchi, and G. pristiophori) with the principal differentiating character being the number of hooks in the principal rows: five in G. adenoplusia and G. heptanchi, six in G. gastrica and G. pristiophori, and seven in G. amblyrhynchos and G. dolichocephala. 
Despite these obvious and potentially superficial differences, some species have a basal swelling and/or a distinctive basal armature (G. adenoplusia, G. gastrica, G. pristiophori, and G. dolichocephala) while other species have neither (G. amblyrhynchos and G. heptanchi). In addition, the adult stage is not known for G. gastrica and G. dolichocephala, while it is incompletely described for G. amblyrhynchos, G. adenoplusia and G. heptanchi. Given these limitations, it is not surprising that the potential generic boundaries between the remaining species of Grillotia appear to be ill-defined.

The material available for the genus Grillotia in existing collections proved to be inadequate for a complete and detailed revision and it is evident that additional collections of new material will be needed to complete descriptions and to delineate the precise relationships between these species. Some molecular data are available, with G. erinaceus, G. pristiophori and $G$. (C.) yuniariae having been included in the molecular phylogenetic analyses of Palm et al. (2009) and Olson et al. (2010). However, while closely related, the data are not adequate to infer relationships within the genus.

Acknowledgements Thanks are due to Mlle Bruni, Institut Océanographique de Monaco, Alain de Chambrier and Jean Mariaux, Muséum d'Histoire naturelle, Geneva, Eileen Harris, British Museum (Natural History) and Helmut Sattmann, Naturhistorisches Museum, Vienna, for providing access to material in collections held in their institutions. Collecting was supported by the Australian Biological Resources Study and other aspects of the study were supported by the National Science Foundation (NSF) PBI awards nos. DEB 0818696 and DEB 0818823.

\section{References}

Bates, R. M. (1990). A checklist of the Trypanorhyncha (Platyhelminthes: Cestoda) of the world (1935-1985). National Museum of Wales, Zoological Series, 1, 1-218.

Bergman, A. (1903). Finnen, Tetrarhynchus-Larven, im Fleische von Heilbutten, Hippoglossus vulgaris Fleming. Fortschritte der Veterinär-Hygiene, Berlin, 7, 212-216 (n.v.).

Beveridge, I. (1990). Revision of the family Gilquiniidae Dollfus (Cestoda: Trypanorhyncha) from elasmobranch fishes. Australian Journal of Zoology, 37, 481-520.

Beveridge, I., \& Campbell, R. A. (2001). Grillotia australis n. sp. and G. pristiophori n. sp. 
(Cestoda: Trypanorhyncha) from Australian elasmobranch and teleost fishes. Systematic Parasitology, 49, 113-126.

Beveridge, I., \& Campbell, R. A. (2007). Revision of the Grillotia erinaceus (van Beneden, 1858) species complex (Cestoda: Trypanorhyncha) with the description of a new species, G. brayi. Systematic Parasitology, 68, 1-31.

Beveridge, I., \& Campbell, R. A. (2010). Validation of Christianella Guiart, 1931 (Cestoda: Trypanorhyncha) and its taxonomic relationship with Grillotia Guiart, 1927. Systematic Parasitology, 76, 111-129.

Beveridge, I., \& Campbell, R. A. (2012). Bathygrillotia n.g. (Cestoda: Trypanorhyncha), with redescriptions of B. rowei (Campbell, 1977) n. comb. and B. kovalevae (Palm, 1995) n. comb. Systematic Parasitology, 82, 249-259.

Beveridge, I., Campbell, R. A., \& Palm, H. (1999). Preliminary cladistic analysis of the cestode order Trypanorhyncha Diesing, 1863. Systematic Parasitology, 42, 29-49.

Beveridge, I., \& Justine, J.-L. (2006). Gilquiniid cestodes (Trypanorhyncha) from elasmobranch fishes off New Caledonia with descriptions of two new genera and a new species. Systematic Parasitology, 65, 235-249.

Beveridge, I., \& Justine, J.- L. (2007). Pseudolacistorhynchus nanus n. sp. (Cestoda: Trypanorhyncha) parasitic in the spiral valve of the zebra shark, Stegostoma fasciatum (Hermann, 1783). Transactions of the Royal Society of South Australia, 132, 177-183.

Campbell, R. A., \& Beveridge, I. (1987). Hornelliella macropora (Shipley \& Hornell, 1906) comb. nov. (Cestoda: Trypanorhyncha) from Australian elasmobranch fishes, and a re-assessment of the family Hornelliellidae. Transactions of the Royal Society of South Australia, 111, $195-200$.

Campbell, R. A., \& Beveridge, I. (1994). Order Trypanorhyncha Diesing, 1863. In: Khalil, L. F., Jones, A. \& Bray, R. A. (Eds) Keys to the cestode parasites of vertebrates. Wallingford: Commonwealth Agricultural Bureaux International, pp. 51-148.

Dollfus, R.-P. (1942). Etudes critiques sur les Tétrarhynques du Muséum de Paris. Archives du Muséum National d'Histoire Naturelle, Paris, 19, 1-466.

Dollfus, R.-P. (1969). De quelques cestodes tétrarhynques (hétéracanthes et pécilacanthes) récoltés chez des poisons de la Méditerranée. Vie et Milieu, Série A, 20, 491-542.

Eschmeyer, W. N. (1998). Catalog of Fishes. San Francisco: California Academy of Sciences, 2905 pp. 
Guiart, J. (1935). Cestodes parasites provenant des Campagnes scientifiques du Prince Albert $1^{\mathrm{er}}$ de Monaco. Résultats des Campagnes scientifiques accomplies sur son yacht par Albert $1^{\text {er }}$ Monaco, 91, 1-115.

Hart, J. F. (1936). Cestoda from fishes of Puget Sound. II. Tetrarhynchoidea. Transactions of the American Microscopical Society, 60, 369-387.

Jones, M. K., Beveridge, I., Campbell, R. A., \& Palm, H. (2004) Terminology of the sucker-like organs of the scolex of trypanorhynch cestodes. Systematic Parasitology, 59, 121-126.

Menoret, A., \& Ivanov, V. A. (2012). Description of plerocerci and adults of a new species of Grillotia (Cestoda: Trypanorhyncha) in teleosts and elasmobranchs from the Patagonian shelf off Argentina. Journal of Parasitology, 98, 1185-1199.

Olson, P. D., Caira, J. N., Jensen, K., Overstreet, R. M., Palm, H. W., \& Beveridge, I. (2010). Evolution of the trypanorhynch tapeworms: parasite phylogeny supports independent lineages of sharks and rays. International Journal for Parasitology, 40, 223-242.

Olsson, P. (1869). Om entozoernas geografiska utbredning och förkomst host olika djur. Forhandlinger ved de skandinaviske Naturforskeres, 10, 481-515.

Palm, H. W. (1995). Untersuchungen zur Sytematik von Rüsselbandwümern (Cestoda: Trypanorhyncha) aus Atlantischen Fischen. Berichte aus dem Intitut für Meereskunde an der Christian Albrechts Universität, Kiel, 275, 1-238.

Palm, H. W. (2004). The Trypanorhyncha Diesing, 1863. Bogor: PKSPL-IPB Press, 710 pp.

Palm H. W., \& Schröder, P. (2001). Cestode parasites from the elasmobranchs Heptranchias perlo and Deania from the Great Meteor Bank, central east Atlantic. Aquatic Living Resources, 14, $137-144$.

Palm, H. W., Waeschenbach, A., Olson, P. D., \& Littlewood, D. T. J. (2009). Molecular phylogeny and evolution of the Trypanorhyncha Diesing, 1863 (Platyhelminthes: Cestoda). Molecular Phylogenetics and Evolution, 52, 351-367.

Pintner, T. (1896). Studien über Tetrarhynchen nebst Beobachtungen an anderen Bandwürmern. II. Mittelung. Über eine Tetrarhynchenlarve aus dem magen von Heptanchus, nebst Bemerkungen über das Excretionssystem verschiedener Cestoden. Sitzungsberichte der Kaiserlichen Akademie der Wissenschaften in Wien. Mathematisch-Naturwissenschaftliche Klasse, 105, 653-682.

Pintner, T. (1903). Studien über Tetrarhynchen nebst Beobachtungen an anderen Bandwürmern. III. Mitteilung. Zwei eigentümliche Drüsensystem bei Rhynchobothrium adenoplusius n. und 
histologische Notizen über Anthocephalus, Amphilina und Taenia saginata. Sitzungsberichte der Kaiserlichen Akademie der Wissenschaften, Mathematisch-Naturwissenschaftliche Klasse, Abt. 1, 122, 541-597.

Pintner, T. (1931). Wenigbekanntes und Unbekanntes von Rüsselbandwümern. II. Sitzungsberichte der Österreichischen Akademie der Wissenschaften, Mathematisch-Naturwissenschaftliche Klasse, Abt. 1, 140, 777-820.

Rees, G. (1944). A new cestode of the genus Grillotia from a shark. Parasitology, 35, 180-185.

Rees, G. (1950). The plerocercoid larva of Grillotia heptanchi (Vaullegeard). Parasitology, 40, $265-272$.

Tseng, S. (1933). [Study on some cestodes from fishes]. Journal of Science of the National University of Shantung, 2, 1-21. [in Chinese].

Vaullegeard, A. (1899). Recherches sur les Tétrarhynques. Mémoires de la Société Linnéenne de Normandie, 19, 187-376.

Wardle, R. A. (1933). The Cestoda of Canadian fishes. III. Additions to the Pacific coastal fauna. Contributions to Canadian Biology and Fisheries, 8, 79-87.

Zschokke, F. (1887). Helmintologische Bemerkungen. Mitteilungen aus der zoologischen Station zu Neapel, 7, 264-271.

\section{Captions to figures:}

Figs. 1-8 Grillotia gastrica n. sp. 1. Scolex. 2. Bulb. 3 - 8. Tentacular armature. 3. Basal region, antibothrial surface. 4. Basal region, oblique view of external surface. 5. Metabasal region, internal surface. 6. Metabasal region, antibothrial surface. 7. Metabasal region, internal surface. 8. Metabasal region, external surface. Scale-bars: 1, 2, $0.1 \mathrm{~mm} ; 3-8,0.01 \mathrm{~mm}$. Drawings from types.

Figs. 9-14 Grillotia heptanchi (Vaullegeard, 1899) Dollfus, 1942. 9. Scolex. 10. Bothrium. 11. Tentacular bulb showing insertion of retractor muscle. 12. Tentacular armature, metabasal region, internal surface. 13. Tentacular armature, metabasal region, antibothrial surface. 14. Tentacular armature, metabasal region, external surface. Scale-bars: $0.1 \mathrm{~mm}$. All figures drawn from material from Hexanchus griseus, Naples (MHNG 37258). A, A' indicates enlarged hook of intercalary row.

Figs. 15-18 Grillotia heptanchi (Vaullegeard, 1899) Dollfus, 1942. 15. Mature segment. 16. Gravid segment. 17. Terminal genitalia. 18. Everted cirrus. Scale-bars: $0.1 \mathrm{~mm}$. Abbreviations: isv, internal 
seminal vesicle; esv, external seminal vesicle; v, vagina. Fig. 16 (gravid segment) drawn from specimen of Hexanchus griseus, Naples (MHNG 40835); remainder drawn from specimens from $H$. griseus, Puget Sound, USA (Tentacularia megabothridia) (MHNG 35732).

Figs. 19-22 Grillotia adenoplusia (Pintner, 1903) Palm, 2004. 19. Scolex. 20. Bothrium. 21. Tentacular bulb. 22. Basal armature, bothrial surface. Scale-bars: 19: 0.1 mm; 21-22, $0.01 \mathrm{~mm}$. Drawings from types.

Figs. 23-26 Grillotia adenoplusia (Pintner, 1903) Palm, 2004. 23. Scolex. 24. Tentacular bulb. 25. Terminal genitalia. 26. Mature segment. Scale-bars: $0.1 \mathrm{~mm}$. Abbreviations: isv, internal seminal vesicle; esv, external seminal vesicle; v, vagina; vd, vas deferens. Figs. 23 and 24 (scolex and bulb) drawn from specimen from Hexanchus griseus, Monterey Bay, USA (MNHN Bd 29.8); Figs. 25 and 26 drawn from specimens from Hexanchus griseus, types of G. spinosissima Dollfus, 1969 (MNHN $\mathrm{Bd}$ 16.34).

Figs. 27-31 Grillotia adenoplusia (Pintner, 1903) Palm, 2004. 27. Basal armature of tentacle, oblique view of internal surface. 28. Basal armature of tentacle, oblique view of external surface. 29. Metabasal armature of tentacle, external surface, starting three hook rows anterior to basal armature. 30. Metabasal armature of tentacle, oblique view of antibothrial surface, starting two hook rows anterior to basal armature. 31. Metabasal armature of tentacle, oblique view of internal surface, starting five rows anterior to basal armature. Scale-bar: $0.01 \mathrm{~mm}$. Intercalary hooks shown in black. All drawings of specimens from Hexanchus griseus, types of G. spinosissima Dollfus, 1969 (MNHN Bd 16.34).

Figs. 32-34 Grillotia dolichocephala Guiart, 1935. 32. Scolex. 33. Basal and metabasal tentacular armature, oblique view of internal/ bothrial surface. 34. Basal tentacular armature, bothrial surface. Scale-bars: $0.1 \mathrm{~mm}$. Drawings from lectotype (IOM Inv 19963-4).

Table 1 Species and species groups currently recognised in the genus Grillotia Guiart, 1927

\section{Grillotia (Grillotia)}


G. (G.) borealis Keeney \& Campbell, 2001

G. (G.) brayi Beveridge \& Campbell, 2007

G. (G.) dollfusi Carvajal, 1971

G. (G.) erinaceus (van Beneden, 1858) (type species)

(syns G. pseuderinaceus Dollfus, 1969;

G. recurvispinis Dollfus, 1969)

G. (G.) musculara (Hart, 1936)

G. (G.) patagonica Menoret \& Ivanov, 2012

\section{Grillotia (Christianella)}

G. (C.) australis Beveridge \& Campbell, 2011

G. (C.) carvajalregorum Menoret \& Ivanov, 2009

(syn. Progrillotia dollfusi Carvajal \& Rego, 1983)

G. (C.) longispinis (Linton, 1890)

G. (C.) minuta van Beneden, 1849

(syns G. angeli Dollfus, 1969; G. bothridiopunctata Dollfus, 1969;

G. smarisgora Wagener, 1854)

G. (C.) yuniariae Palm, 2004

\section{Grillotia sensu lato}

G. adenoplusia (Pintner, 1903)

(syns G. acanthoscolex Rees, 1944; G. spinosissima Dollfus, 1969;

G. microthrix Dollfus, 1969)

G. amblyrhynchos Campbell \& Beveridge, 1993

G. dolichocephala Guiart, 1935

(syns G. minor Guiart, 1935; G. meteori Palm \& Schröder, 2001)

G. heptanchi (Vaullegeard, 1899)

G. pristiophori Beveridge \& Campbell, 2001

\section{Species inquirendae}

G. hippoglossi (Olsson, 1869)

G. scolecina (Rudolphi, 1819) 


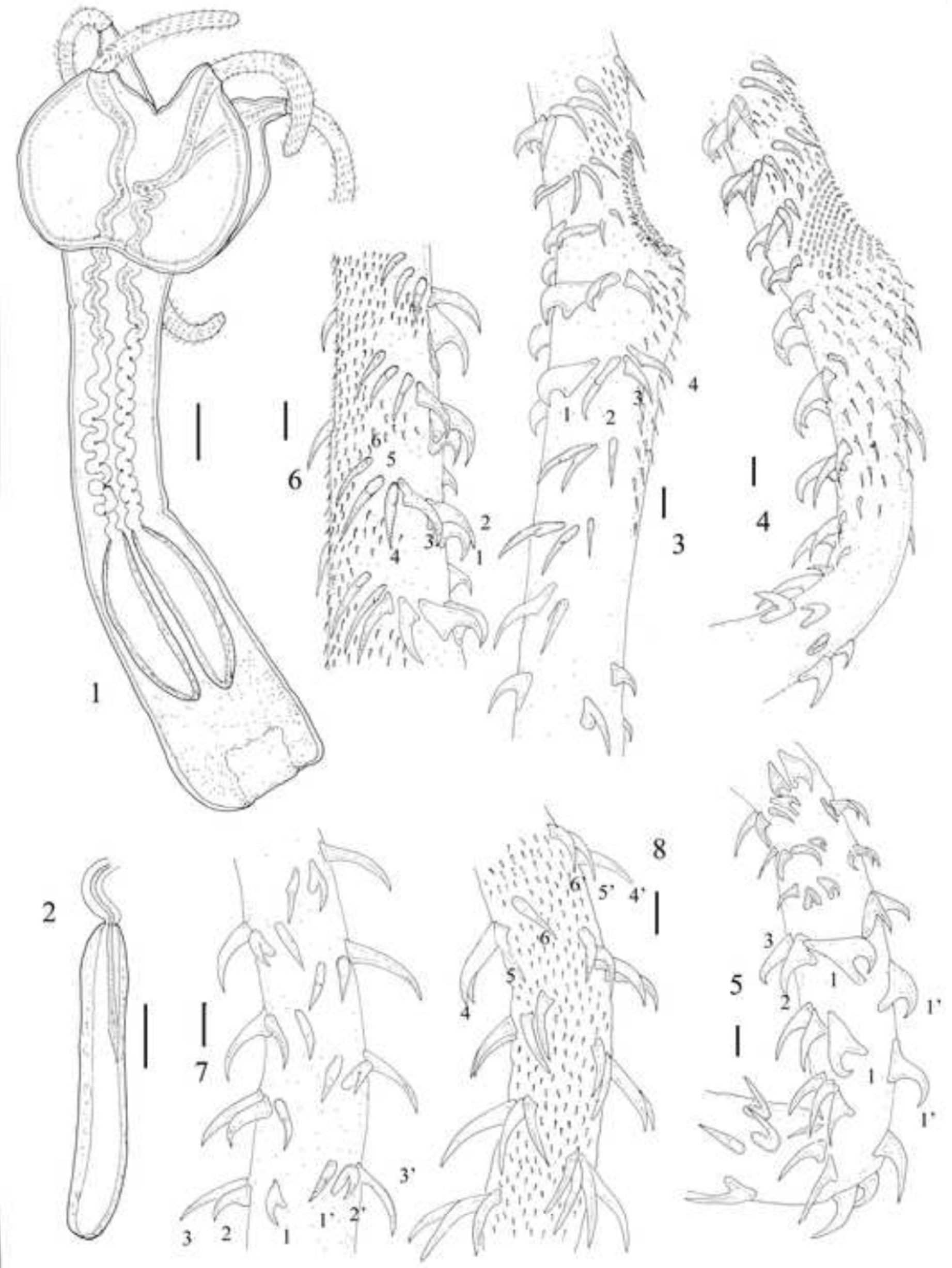



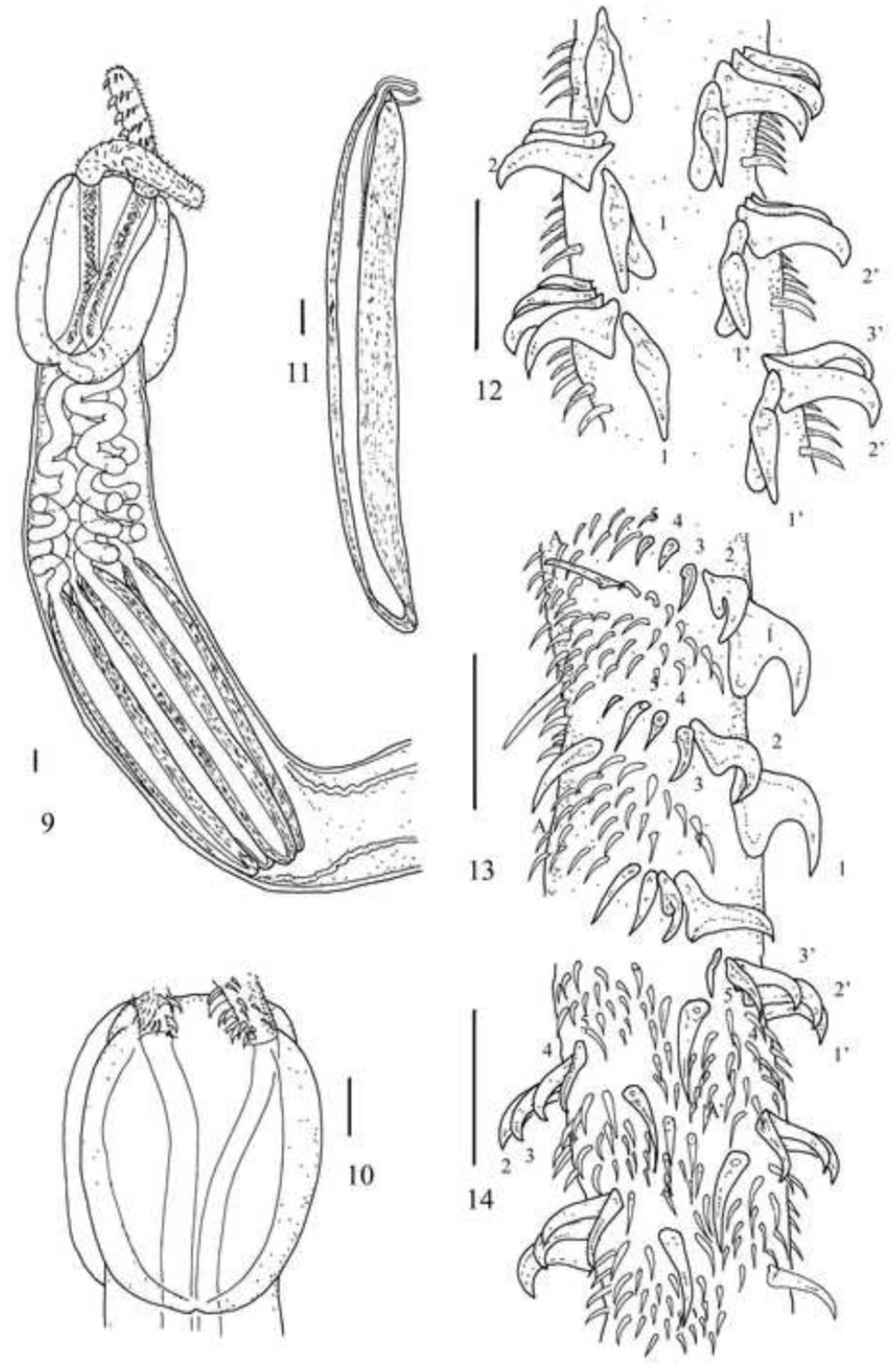

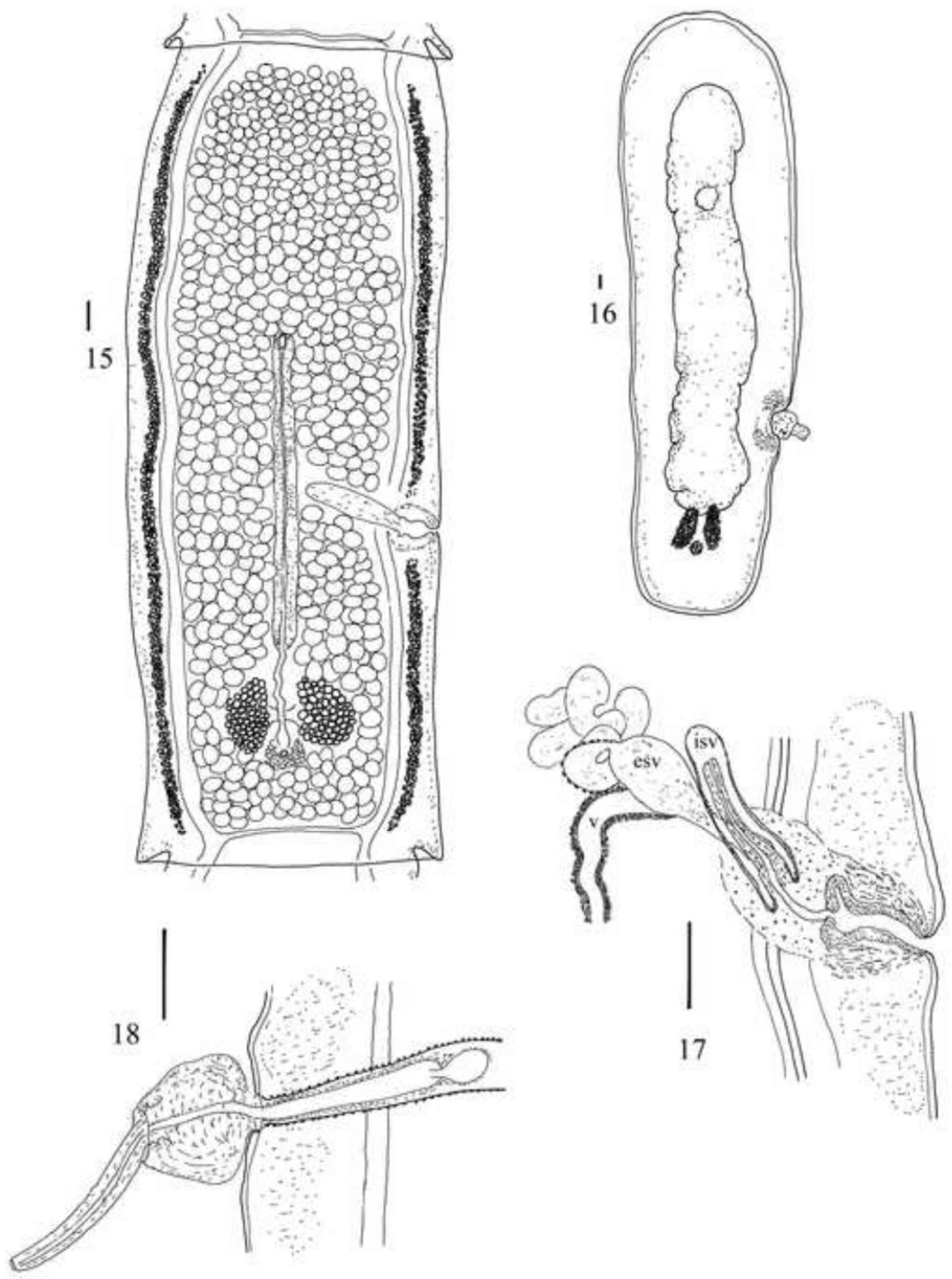


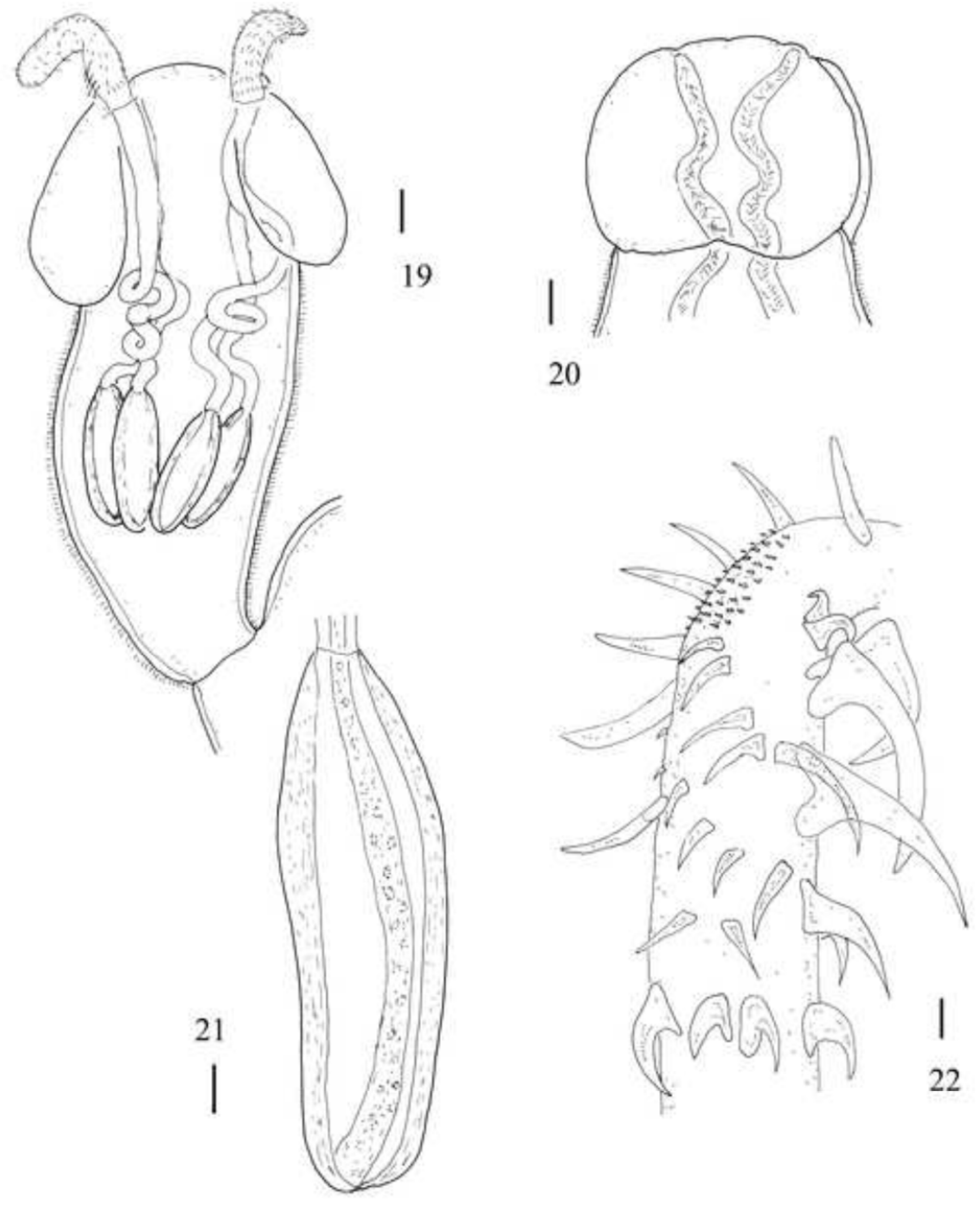



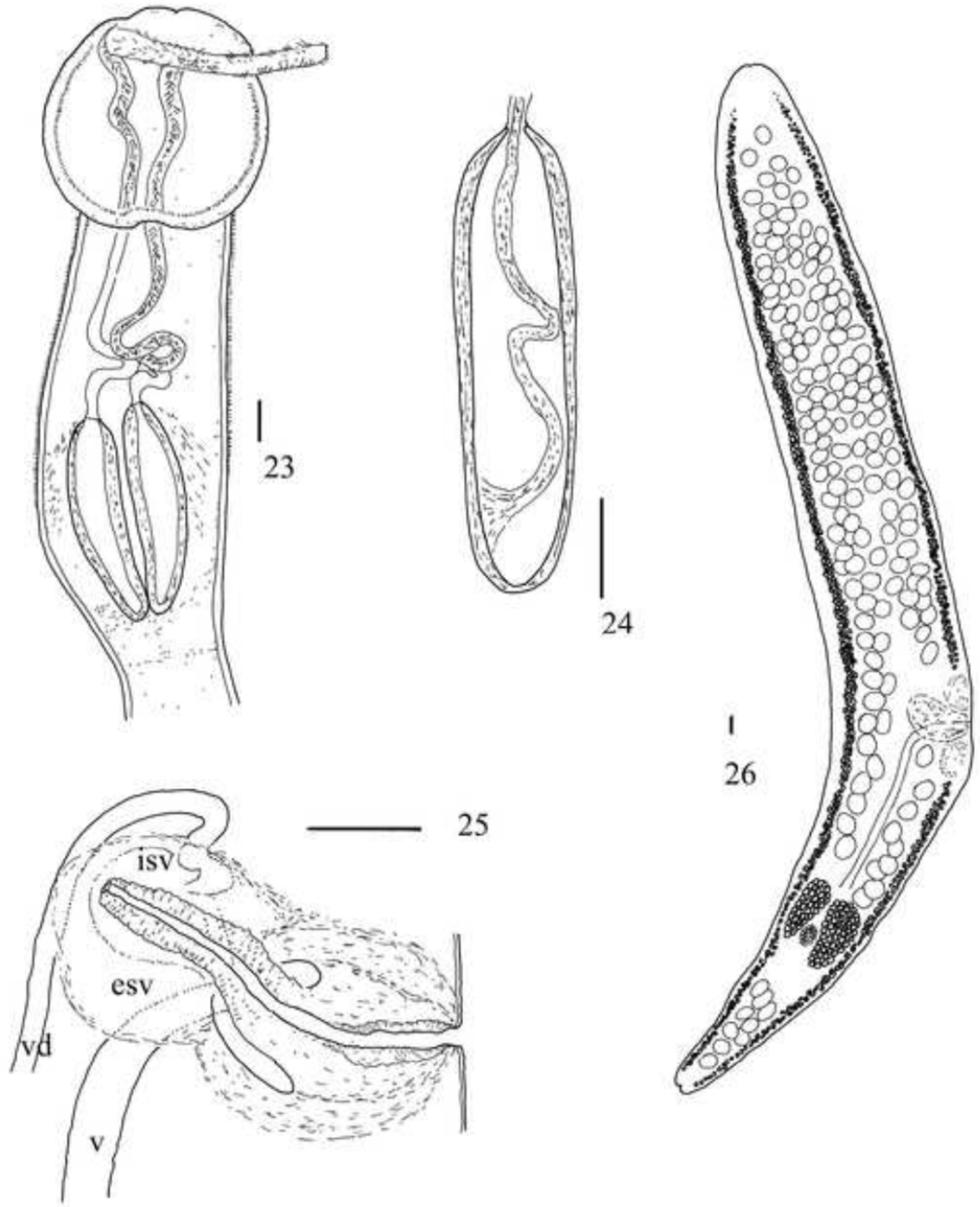

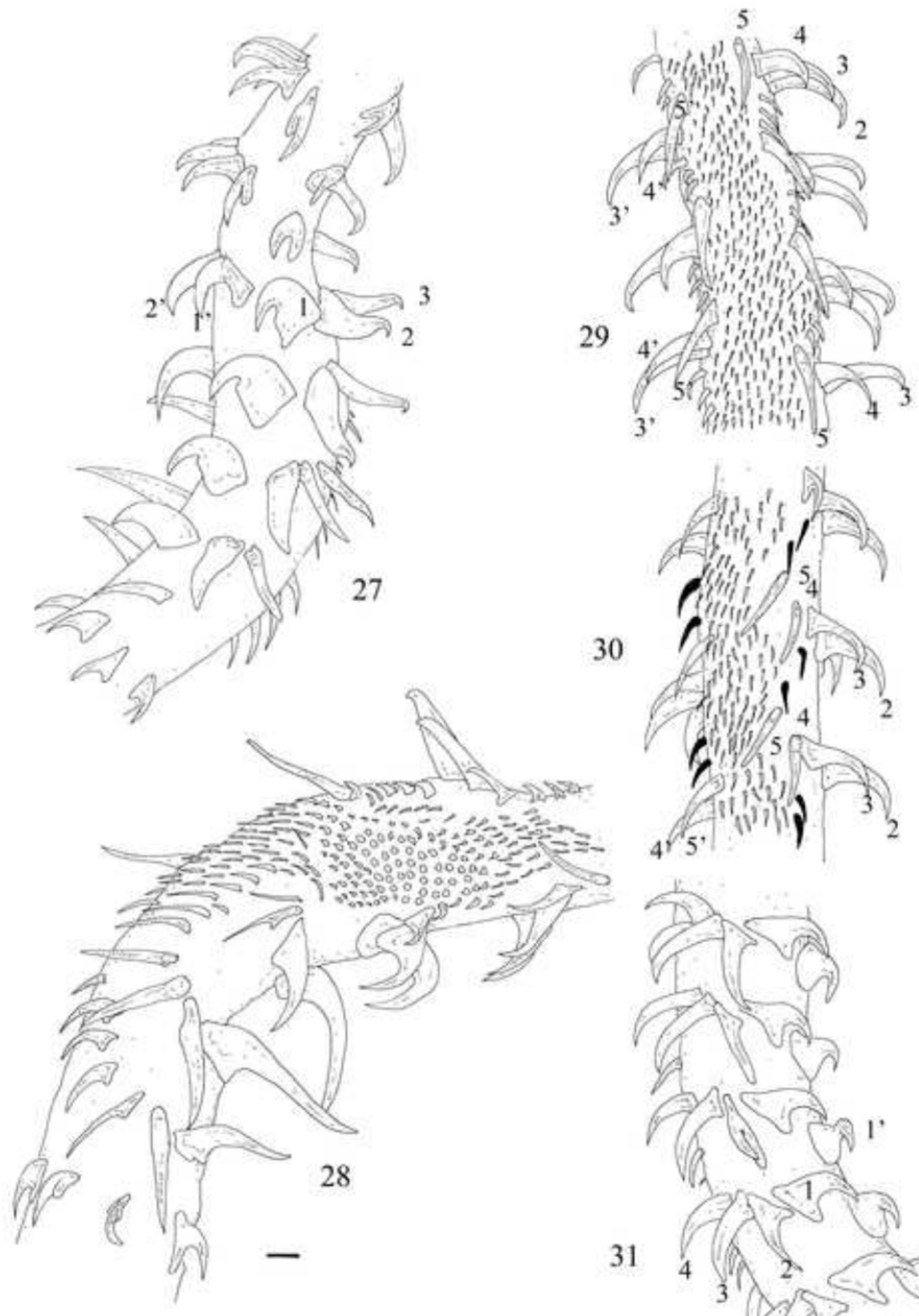

30
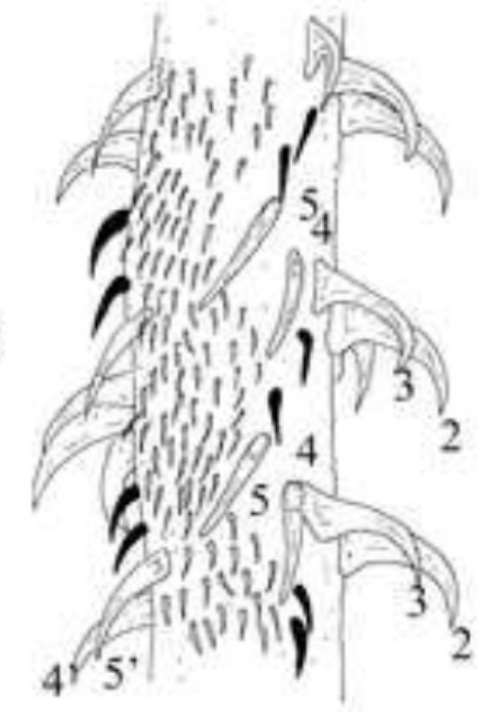

31

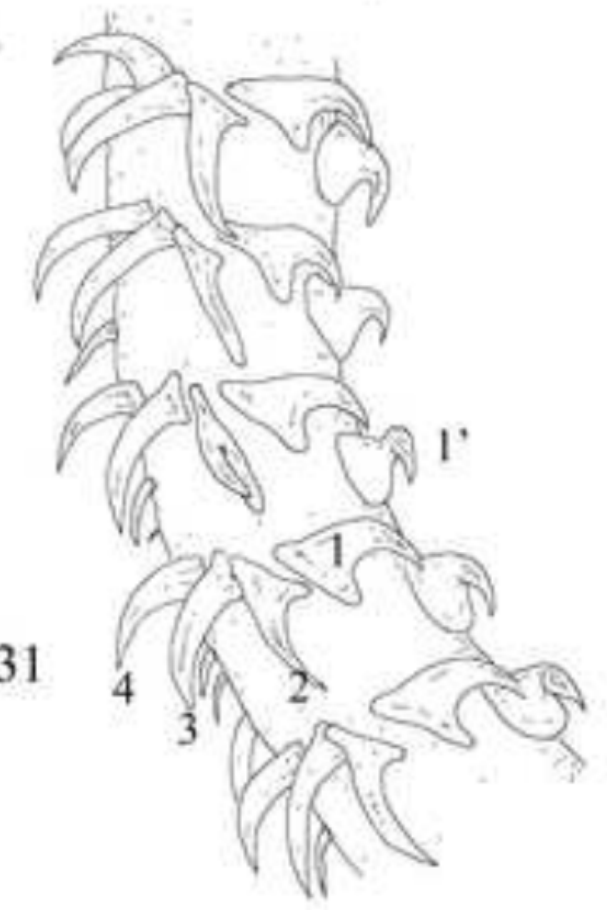



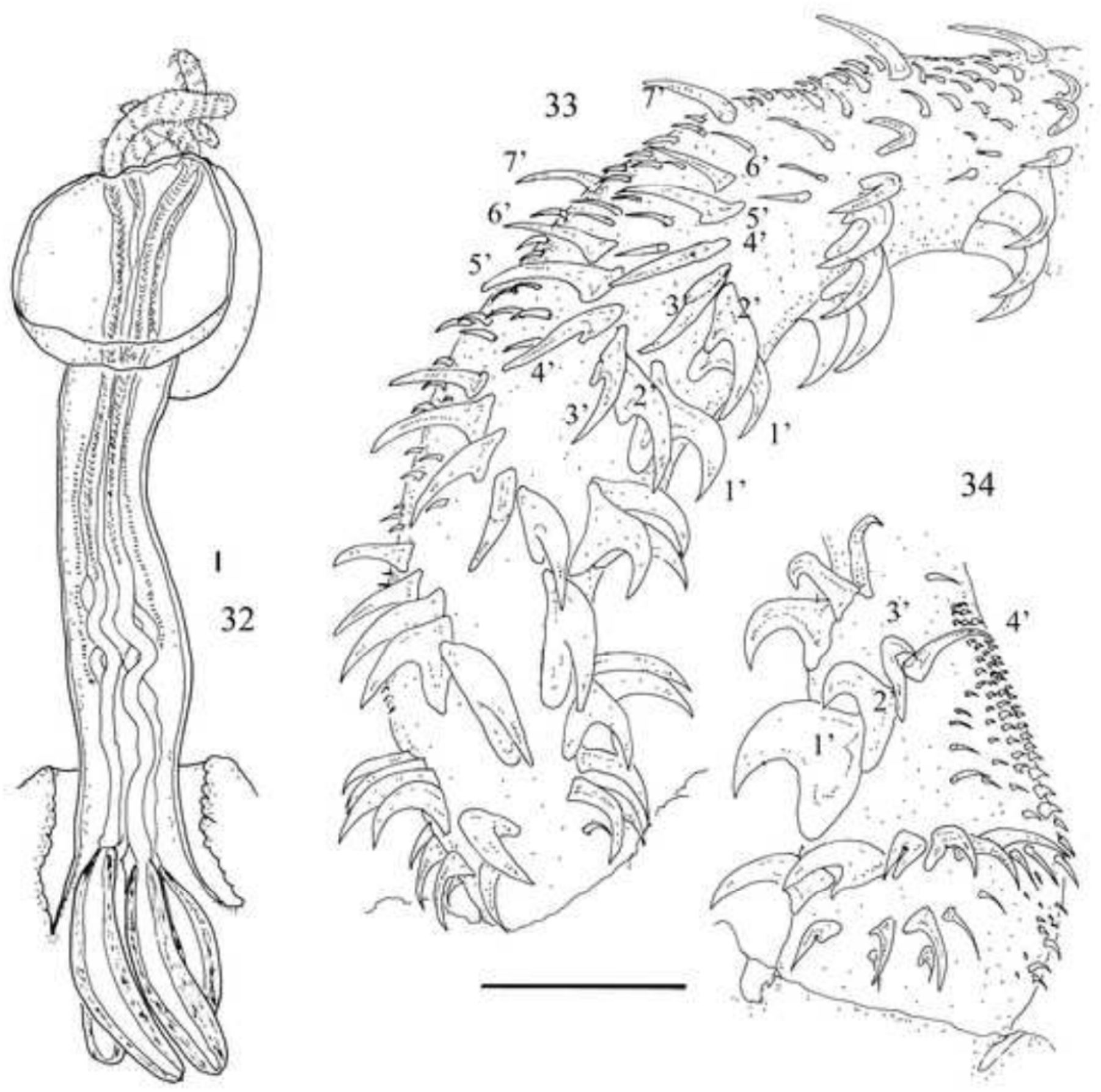


\section{University Library}

\section{- $\mathrm{M}$ IIN E R VA A gateway to Melbourne's research publications}

Minerva Access is the Institutional Repository of The University of Melbourne

Author/s:

Beveridge, I;Campbell, RA

Title:

A new species of Grillotia Guiart, 1927 (Cestoda: Trypanorhyncha) with redescriptions of congeners and new synonyms

Date:

2013-06-01

Citation:

Beveridge, I. \& Campbell, R. A. (2013). A new species of Grillotia Guiart, 1927 (Cestoda: Trypanorhyncha) with redescriptions of congeners and new synonyms. SYSTEMATIC PARASITOLOGY, 85 (2), pp.99-116. https://doi.org/10.1007/s11230-013-9416-9.

Persistent Link:

http://hdl.handle.net/11343/283301 